\title{
Description of the male and the larva of Ixodes collaris Hornok, 2016 with drawings of all stages
}

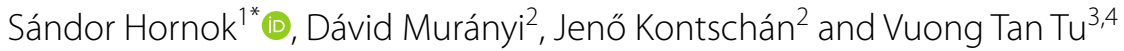

\begin{abstract}
Background: Ixodes collaris Hornok, 2016 is a recently discovered tick species associated with bats in Asia. This study provides the description of the male and the larva, as well as high quality drawings of all stages.

Methods: Ticks were collected from cave walls and bats in Phia Oac (Vietnam). DNA was extracted from one individual of each stage/sex, while another was morphometrically analysed. Based on two genetic markers, all ticks were identified as I. collaris.

Results: The male of I. collaris has long legs (i.e. the length of Haller's organ exceeds the maximum diameter of tarsus I), unlike the male of I. simplex Neumann, 1906, but similarly to males of I. vespertilionis Koch, 1844 and I. ariadnae Hornok, 2014. The lateral and medial edges of the palpi of male I. collaris are both convexly curved, unlike in I. ariadnae and I. simplex, but similarly to I. vespertilionis. The male of I. collaris has long palpal setae (up to $210 \mu \mathrm{m}$ ), unlike the

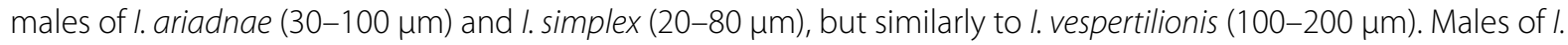
collaris have sparse distribution of long palpal setae (vs dense in I. vespertilionis) and posteriorly diverging, sclerotized trapezoid ridge dorsally on the basis capituli (posteriorly convergent, U-shaped and less evident in I. vespertilionis). The larva of I. collaris has long legs (unlike the larva of I. simplex, but similarly to I. vespertilionis and I. ariadnae), elongated club-shaped palpi $(240 \times 70$ vs $200 \times 90 \mu \mathrm{m}$ in I. ariadnae, $200 \times 70 \mu \mathrm{m}$ in I. vespertilionis; and $140 \times 60 \mu \mathrm{m}$ in I. simplex:), pentagonal scutum, which is longer than broad (different from I. ariadnae and I. simplex, but similar to that of I. vespertilionis). The larva of I. collaris has strongly concave caudolateral margin of ventral basis with perpendicular angle (vs slightly concave, with obtuse angle in I. vespertilionis) and a prominent, dark sclerotized edge, "collar" (absent in I. vespertilionis).
\end{abstract}

Conclusion: Several features allow to distinguish the male and the larva of I. collaris morphologically from those of other bat-associated ixodid tick species.

Keywords: Ixodes collaris, Bat tick, Cave, Male, Larva, Description

\section{Background}

In a recent Eurasian survey on ixodid ticks infesting bats, high degree of mitochondrial gene heterogeneity of Ixodes vespertilionis Koch, 1844 was reported, postulating that it is actually a species complex, within which hitherto unknown or formerly not distinguished bat tick species might exist [1]. Accordingly, I. collaris Hornok,

\footnotetext{
*Correspondence: hornok.sandor@univet.hu

1 Department of Parasitology and Zoology, University of Veterinary Medicine, Budapest, Hungary

Full list of author information is available at the end of the article
}

2016, has been described, based on material from the intermediate horseshoe bats (Rhinolophus affinis) in Vietnam. However, the description of this new species was based only on the female and the nymph [2], because at that time male bat ticks were not seen on cave walls and larvae could not be collected from the only known host species.

This study provides the description of the male and the larva of I. collaris, in order to complete the description of the species. In addition, because detailed drawings of the female and the nymph of $I$. collaris have not been

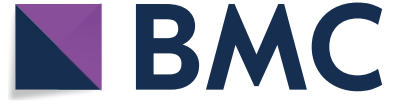

(c) The Author(s) 2019. This article is distributed under the terms of the Creative Commons Attribution 4.0 International License (http://creativecommons.org/licenses/by/4.0/), which permits unrestricted use, distribution, and reproduction in any medium, provided you give appropriate credit to the original author(s) and the source, provide a link to the Creative Commons license, and indicate if changes were made. The Creative Commons Public Domain Dedication waiver (http://creativecommons.org/ publicdomain/zero/1.0/) applies to the data made available in this article, unless otherwise stated. 
available, high quality drawings of its all stages are also provided here.

\section{Methods}

\section{Sample collection}

Ixodes sp. ticks (two individuals per stage or sex) were collected at a cave located in the buffer zone of Phia Oac, Phia Den National Park (22.563611N, 105.874167E), Cao Bang Province, Vietnam (i.e. the type-locality of $I$. collaris) on June 1, 2016 and November 17, 2017. Male ticks were removed from cave walls, whereas females, nymphs and larvae were collected from $R$. affinis. All specimens were stored in $96 \%$ ethanol. After microscopical evaluation of their conspecificity, DNA was extracted from one individual of each stage/sex, while the other was morphometrically analysed and described. Specimens of $I$. vespertilionis (used for comparison) were collected in Leány cave, Hungary.

\section{Sample analyses}

From the DNA extracts, molecular analyses of two mitochondrial markers were performed as reported [1] by two PCRs: the first amplifying an approximately $710 \mathrm{bp}$ long fragment of the cytochrome $c$ oxidase subunit 1 ( $\operatorname{cox} 1)$ gene with the primers HCO2198 (5'-TAA ACT TCA GGG TGA CCA AAA AAT CA-3') and LCO1490 (5'GGT CAA CAA ATC ATA AAG ATA TTG G-3'), and the second targeting an approximately $460 \mathrm{bp}$ fragment of the $16 \mathrm{~S}$ rRNA gene of Ixodidae with the primers $16 \mathrm{~S}$ +1 (5'-CTG CTC AAT GAT TTT TTA AAT TGC TGT GG-3') and 16S-1 (5'-CCG GTC TGA ACT CAG ATC AAG T-3'). PCR products were visualized in a $1.5 \%$ agarose gel. Purification and sequencing was done by Biomi Inc. (Gödöllô, Hungary). Sequences were compared to those already deposited in GenBank by nucleotide BLASTN program (https://blast.ncbi.nlm.nih.gov).

Pictures and measurements were made with a VHX5000 (Keyence Co., Osaka, Japan) digital microscope.

\section{Results}

Based on the amplified fragment of their cox 1 and $16 S$ rRNA genes, all ticks described here were identified as I. collaris, having $100 \%$ sequence identity to formerly reported female and nymph specimens of this tick species ( $\operatorname{cox} 1$ gene: KR902756, $16 S$ rRNA gene: KR902771). The newly generated sequences were submitted to the GenBank database under the accession
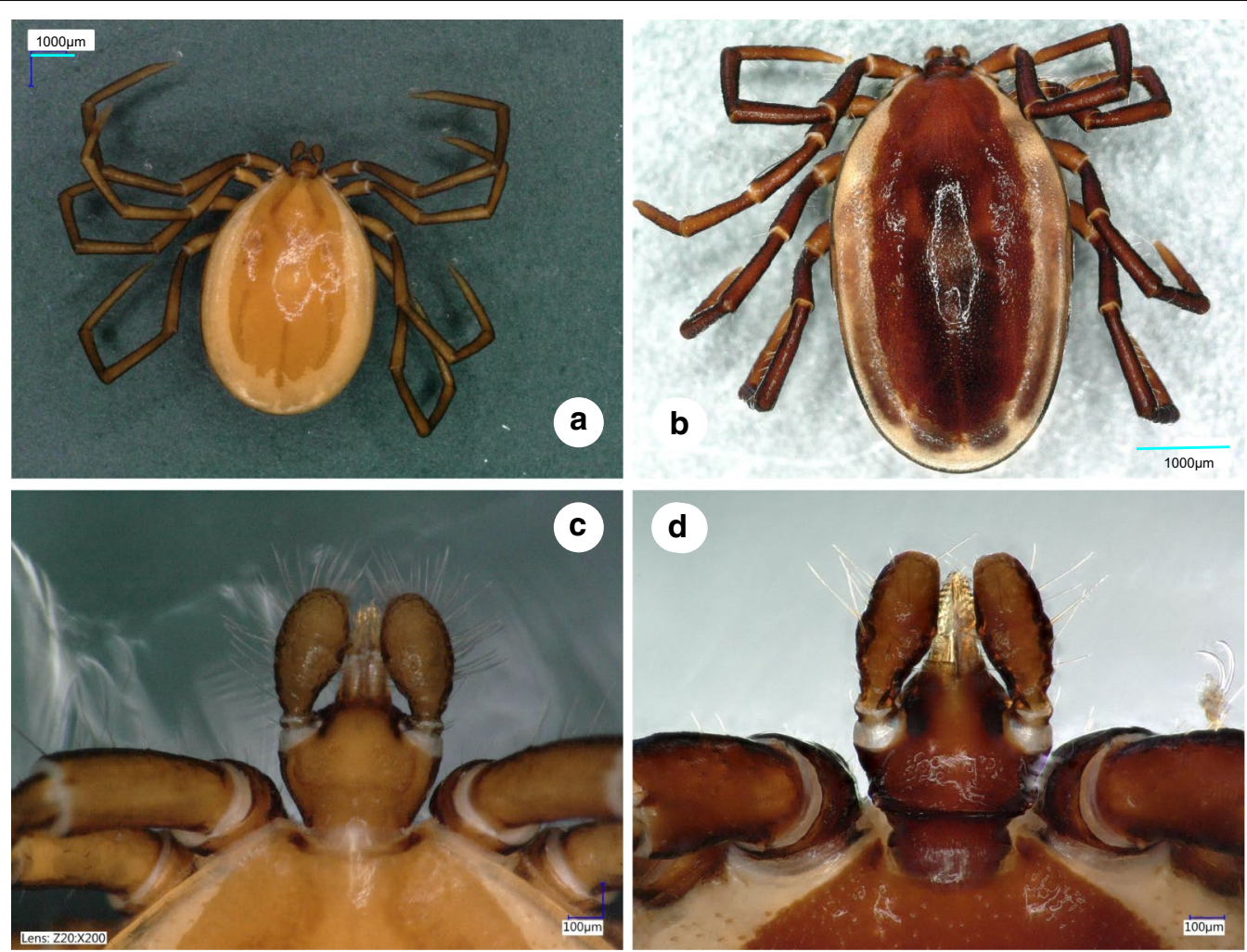

Fig. 1 Dorsal views of male lxodes vespertilionis (a, habitus; $\mathbf{c}$, gnathosoma) and I. collaris (b, habitus; $\mathbf{d}$, gnathosoma) 

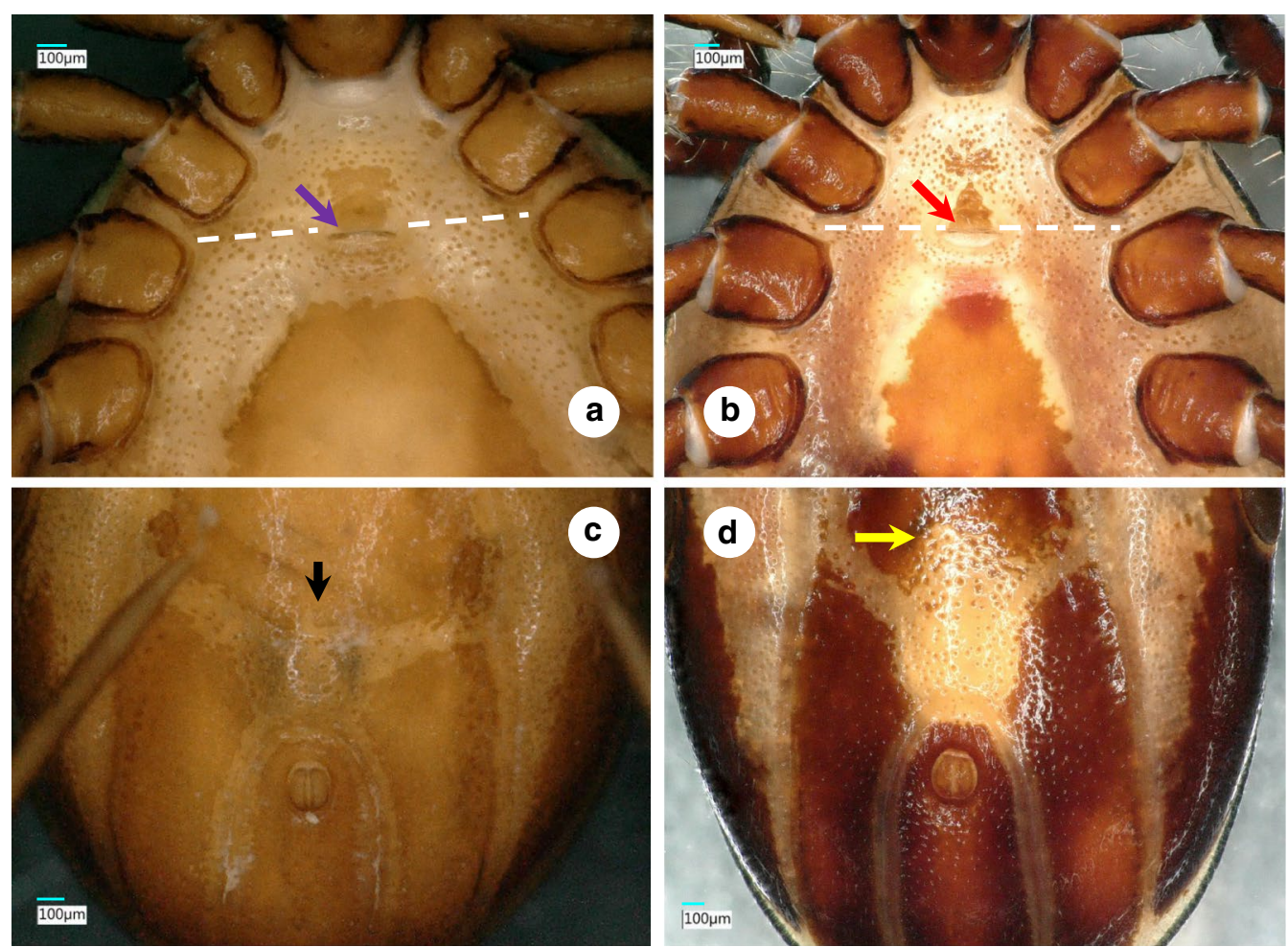

Fig. 2 Ventral views of male Ixodes vespertilionis ( $\mathbf{a}$, anterior part of the idiosoma; $\mathbf{c}$, posterior part of the idiosoma) and I. collaris ( $\mathbf{b}$, anterior part of the idiosoma; $\mathbf{d}$, posterior part of the idiosoma). The white dashed line indicates the second intercoxal space. The purple and red arrows show the genital aperture. The black and yellow arrows point to differences in the anterior part of the ivory coloration

numbers MK450318-MK450319 (cox1) and MK450320MK450321 (16S rRNA). The measurements in the descriptions below are provided in millimetres.

\section{Ixodes collaris Hornok, 2016}

\section{Description}

Male. [See Figs. 1-3.] Length of idiosoma (from half point between scapular apices to posterior margin) 4.49 , breadth 2.78, ratio of idiosomal length/breadth 1.61. Conscutum centrally dark brown, laterally lightly colored, elongated, elliptical, broadest slightly anteriorly to its mid-length (Fig. 1b). Length of scutum 4.2, breadth 2.45, ratio length/breadth 1.71. Cervical grooves anteriorly well-defined, paramedian grooves posteriorly shallow; scattered punctuations present. Genital aperture at level of second intercoxal space, surrounded by ivory color and scattered punctuations (Fig. 2b). Spiracular plates slightly oval (length/breadth ratio 1.23), with eccentric opening. Ivory coloration anterior to anus oval, elongated. Anal plate oval, elongated, broadest at midlength. Adanal plates 1.5 times longer than anal plate. Median plate anteriorly rounded, longer than broad (Figs. 2b, d, 3b).
Gnathosoma: length from palpal apices to posterior margin of basis 0.78 , width of basis dorsally 0.48 , ratio of length to width 1.63. Basis capituli dorsally broadest at base of palpi, with laterally and posteriorly elevated, backwardly diverging (trapezoid), dark, sclerotized ridge (Fig. 1d). Basis capituli ventrally trapezoidal, posteriorly tapering (Fig. 2b). Palpi relatively short, length (dorsally) 0.53 , breadth 0.21 , ratio length/breadth 2.52. Palpal segment I. 0.04, II-III (with indistinct separation) 0.48 long. Segments II-III curved both medially and laterally, with uneven surface (Fig. 1d). Palpal setae long anteriorly, showing sparse distribution laterally (less than 10 in number), on segments II-III up to 0.21 long (i.e. equal to width of palpi (Fig. 1d). Hypostome conical, length 0.26 , breadth at basis 0.15 , ratio length/breadth 1.73 . Teeth poorly defined, with dental formula $3 / 3$.

Legs long. Haller's organ elongated, longer than maximum breadth (diameter) of tarsus I (length: 1.37). Coxae medially rounded, without spines or spurs, but with short (0.07) setae (Figs. 2b, 3b).

Larva. [See Figs. 4-6.] Length of idiosoma 0.96, breadth 0.76 , ratio idiosomal length/breadth 1.26 . Scutum pentagonal, posteriorly rounded, broadest slightly anteriorly 


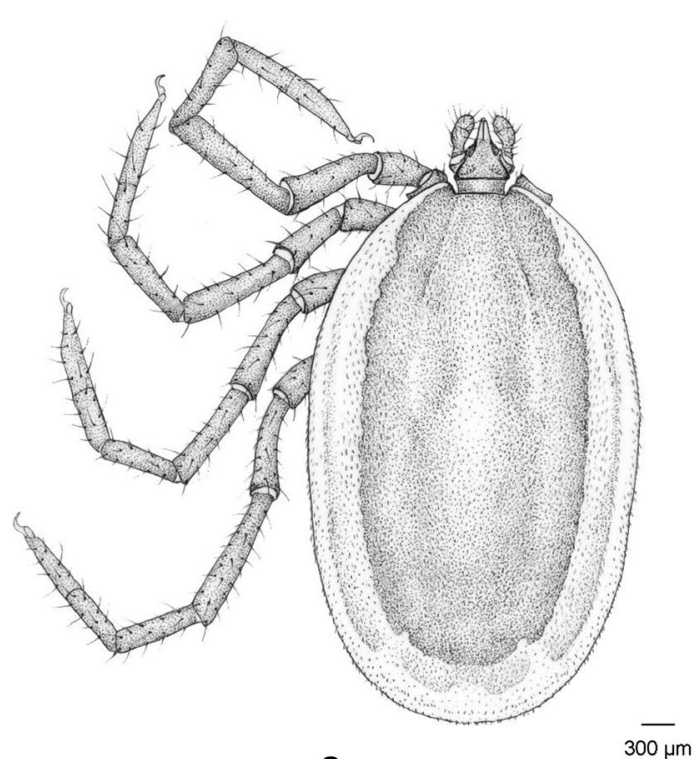

a

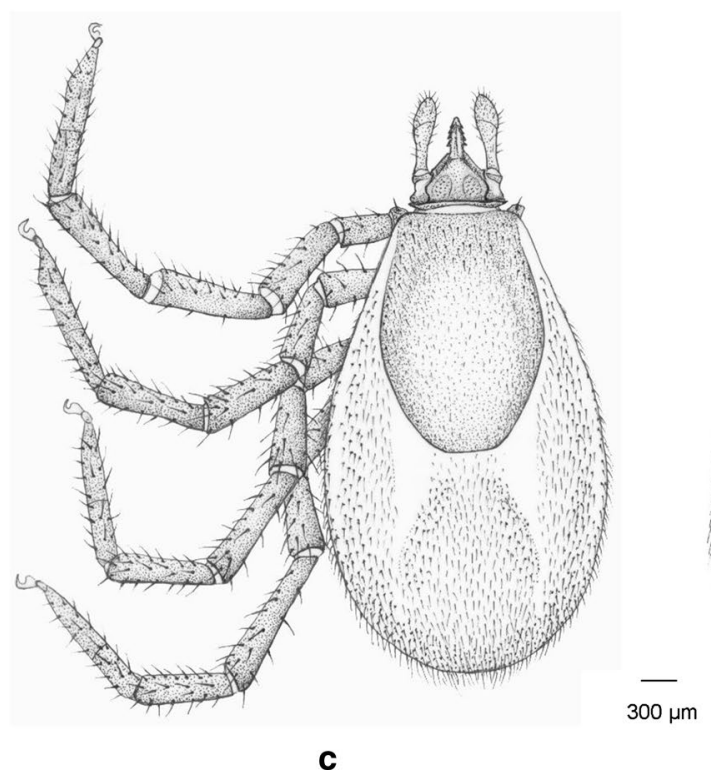

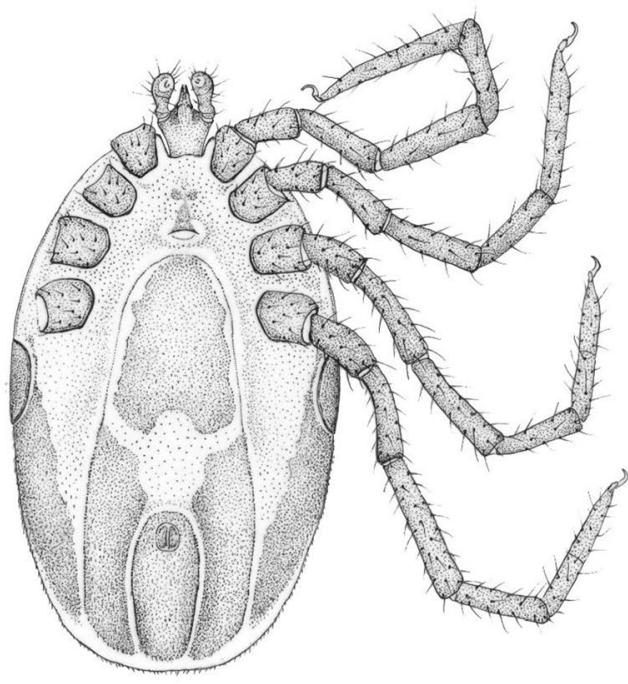

b

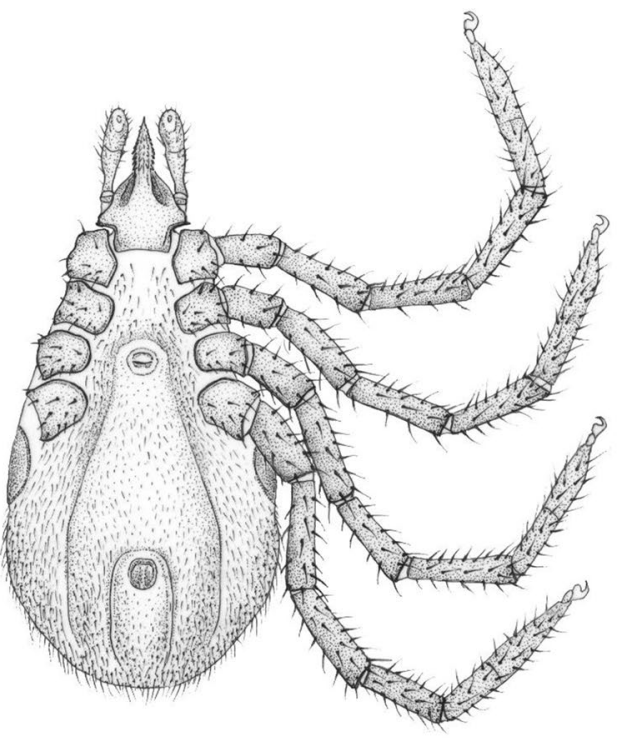

d

Fig. 3 Drawings of /xodes collaris male (a, dorsal view; $\mathbf{b}$, ventral view) and female (c, dorsal view; d, ventral view)

to its mid-length (Fig. 4b), with rough surface. Length of scutum 0.52 , breadth 0.49 , ratio length/breadth 1.06 . Cervical grooves long, ending at deepest point of concavely curved posterolateral margin of scutum (Fig. 4b). Scutal setae absent. Alloscutal setae longest caudally; central dorsal setae (Cd1: 0.045, Cd2: 0.047) shorter than marginal dorsal setae (Md1-Md8: 0.088, 0.096, 0.105, $0.112,0.125,0.108,0.133$ and 0.148 , respectively). Sternal setae ventrally (St1: 0.056, St2: 0.051; St3: 0.062) shorter than premarginal setae (Pm1-Pm4: 0.072, 0.075, 0.076 and 0.071 , respectively) and preanal setae (Pa1: 0.064;
Pa2: 0.078); marginal ventral setae longest (Mv1: 0.092; Mv2: 0.118; Mv3: 0.128) (Fig. 5c, d).

Gnathosoma: length from palpal apices to posterior margin of basis 0.34 , width of basis capituli dorsally 0.25 , ratio of length to width 1.36 . Basis capituli dorsally triangular, with straight posterior margin. Ventral basis with 2 pairs of short (0.015) posthypostomal setae. Strongly concave caudolateral margin of ventral basis with perpendicular angle and dark sclerotized edge ("collar") at and behind maximum width of basis (Fig. 6b). Posterior margin of ventral basis rounded (Fig. 6b). Palpi elongated, 


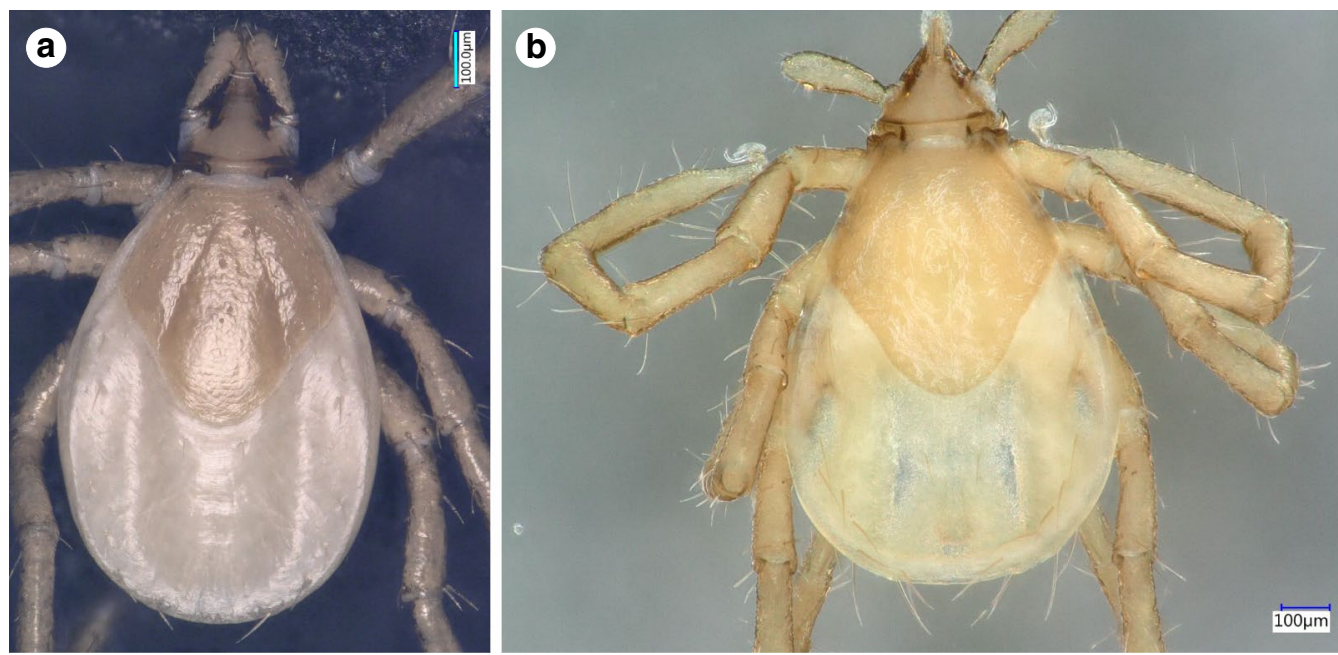

Fig. 4 Dorsal view of Ixodes vespertilionis (a) and I. collaris (b) larvae

club-shaped, curved both medially and laterally. Palpal length dorsally 0.24 , breadth 0.07 , ratio length/breadth 3.4. Segments I-III measure $0.03,0.13$ and 0.08 , respectively. Palpal setae longest (0.06) near junction of segments II-III. Hypostome conical, short (0.11), with dental formula $2 / 2$.

Legs long. Haller's organ elongated, longer than maximum breadth (diameter) of tarsus I (length: 0.48) (Figs. 4b, 5c, d, 6d,). Coxae medially rounded, without spines or spurs. Medial margins of coxae I-II straight, nearly equal in length; those of coxae III rounded (Fig. 6d). Coxae I-II with short (0.04) setae (2 and 1, respectively: Fig. 5d).

\section{Differential diagnosis}

Prior to its discovery, I. collaris may have been misidentified as I. vespertilionis in Southeast Asia (e.g. in [3]). Therefore, the differential diagnosis (see Figs. 1, 2, 4 and 6) focuses on the latter species, as redescribed in [4] and [5]. Apart from data taken from the latter source on larvae of I. simplex Neumann, 1906, the redescription of the male of I. simplex was also taken into account [6], together with measurements (including those of $I$. ariadnae Hornok, 2014) in [7].

The male of $I$. collaris has long legs (i.e. the length of Haller's organ exceeds the maximum diameter of tarsus I), unlike the male of I. simplex. The palpi of I. collaris male have convexly curved lateral and medial edges, unlike the males of I. ariadnae (where the lateral edge is straight) and I. simplex (where the lateral edge is bent at an angle). The palpal setae are long (up to $210 \mu \mathrm{m}$ ), unlike in the males of $I$. ariadnae $(30-100 \mu \mathrm{m})$ and I. simplex $(20-80 \mu \mathrm{m})$. The most important features to distinguish males of I. collaris from those of I. vespertilionis are on the gnathosoma: (i) more elongated palpi (length to breadth ratio 2.52 vs 2.0-2.1) (Fig. 1d vs 1c); (ii) the sparse distribution and low number $(<10)$ of long anterior and lateral palpal setae, which show dense distribution and higher number $(>20)$ in I. vespertilionis (Fig. 1c); and (iii) the posteriorly diverging (trapezoid), sclerotized ridge dorsally on the basis capituli, which is much less conspicuous and posteriorly converging (U-shaped) in $I$. vespertilionis (Fig. 1c). In addition, (iv) the idiosoma of male $I$. collaris is more elongated than the idiosoma of male $I$. vespertilionis (length to breadth ratio $1.61 v s$ 1.35, Fig. $1 \mathrm{~b} v s \mathrm{a}$ ) and (v) ventrally the ivory coloration anterior to the anus is oval, elongated in I. collaris, whereas this is less apparent in I. vespertilionis (Fig. 2c).

The larva of $I$. collaris has long legs, unlike the larva of I. simplex (in which the legs are short, i.e. the length of Haller's organ does not exceed the maximum diameter of tarsus I). The palpi of I. collaris larva are elongated, club-shaped, with a length to breadth ratio above three (length $\times$ width: $240 \times 70 \mu \mathrm{m}$ ), unlike in $I$. vespertilionis (Fig. 6a: club shaped, but shorter, $200 \times 70 \mu \mathrm{m}$ ), I. ariadnae (shorter and broader, $200 \times 90 \mu \mathrm{m}$, laterally straight) and $I$. simplex (shorter and narrower, $140 \times 60 \mu \mathrm{m}$ ). The scutum of $I$. collaris larva is longer than broad, pentagonal, with long cervical grooves, ending at the deepest point of the concavely curved posterolateral margin of scutum (unlike in case of I. ariadnae and I. simplex). The most important features to distinguish the larva of I. collaris from that of I. vespertilionis can be observed ventrally on the basis capituli: (i) its caudolateral edge is strongly concave in case of I. collaris, showing perpendicular angle at the concavity, whereas it is only slightly 


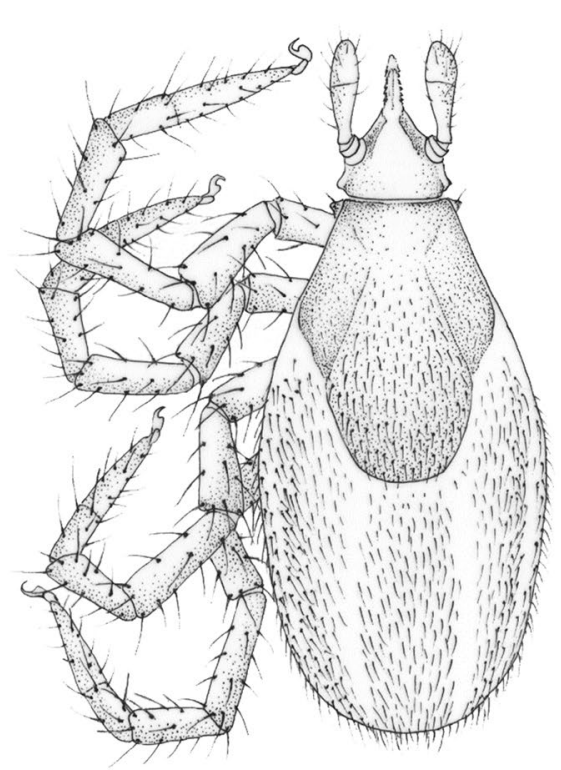

a

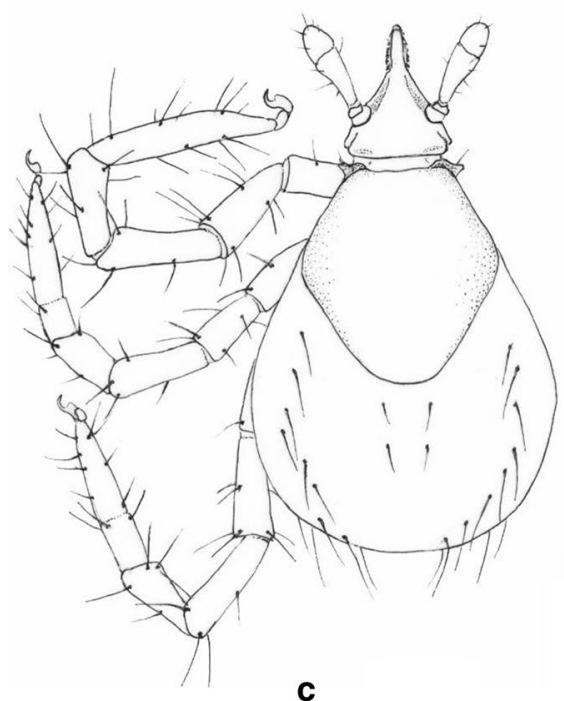

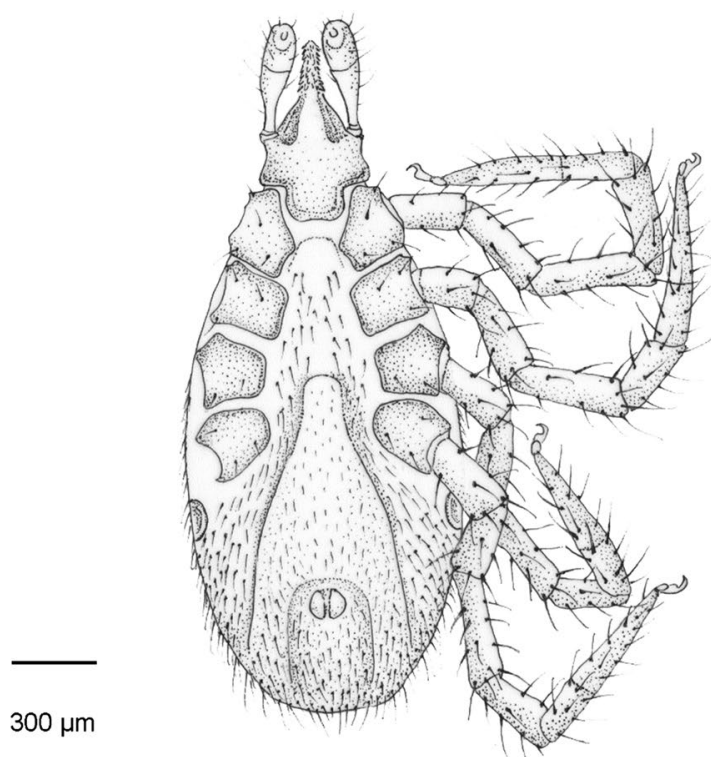

b

$300 \mu \mathrm{m}$

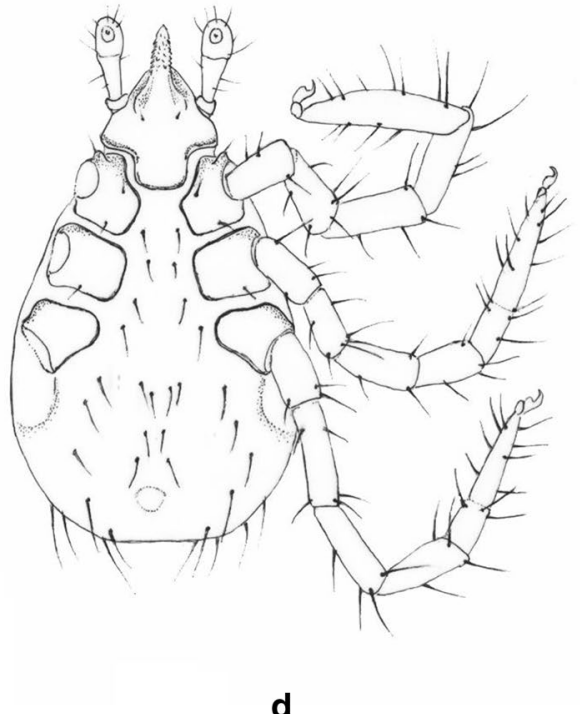

Fig. 5 Drawings of /xodes collaris nymph (a, dorsal view; $\mathbf{b}$, ventral view) and larva (c, dorsal view; d, ventral view)

concave, with an obtuse angle, in I. vespertilionis (Fig. 6a); and (ii) at/behind the maximum breadth of ventral basis, the presence of a conspicuous, long, dark sclerotized edge ("collar") also makes I. collaris larvae different from I. vespertilionis larvae, where this structure is less apparent (Fig. 6b vs 6a). In addition, (iii) caudal setae on the idiosoma are considerably longer than $100 \mu \mathrm{m}$ in I. collaris larvae, unlike in I. vespertilionis larvae $(\leq 100 \mu \mathrm{m}$, see Figs. 4a and 6c); and (iv) the medial edge of coxa I is much shorter than that of coxa II in I. vespertilionis larvae (Fig. 6c), as contrasted to I. collaris larvae.

\section{Discussion}

With the morphological characters, high resolution pictures and drawings provided in the present study, descriptions of all stages of $I$. collaris are now complete. Adding to already reported genetic differences between I. vespertilionis, I. collaris, I. ariadnae and I. simplex [1], these ixodid bat tick species show different morphology in all stages, as shown formerly for females and nymphs [2] and here for males and larvae.

In summary, short legs distinguish all stages of I. simplex from I. collaris. Ixodes ariadnae has laterally straight and 

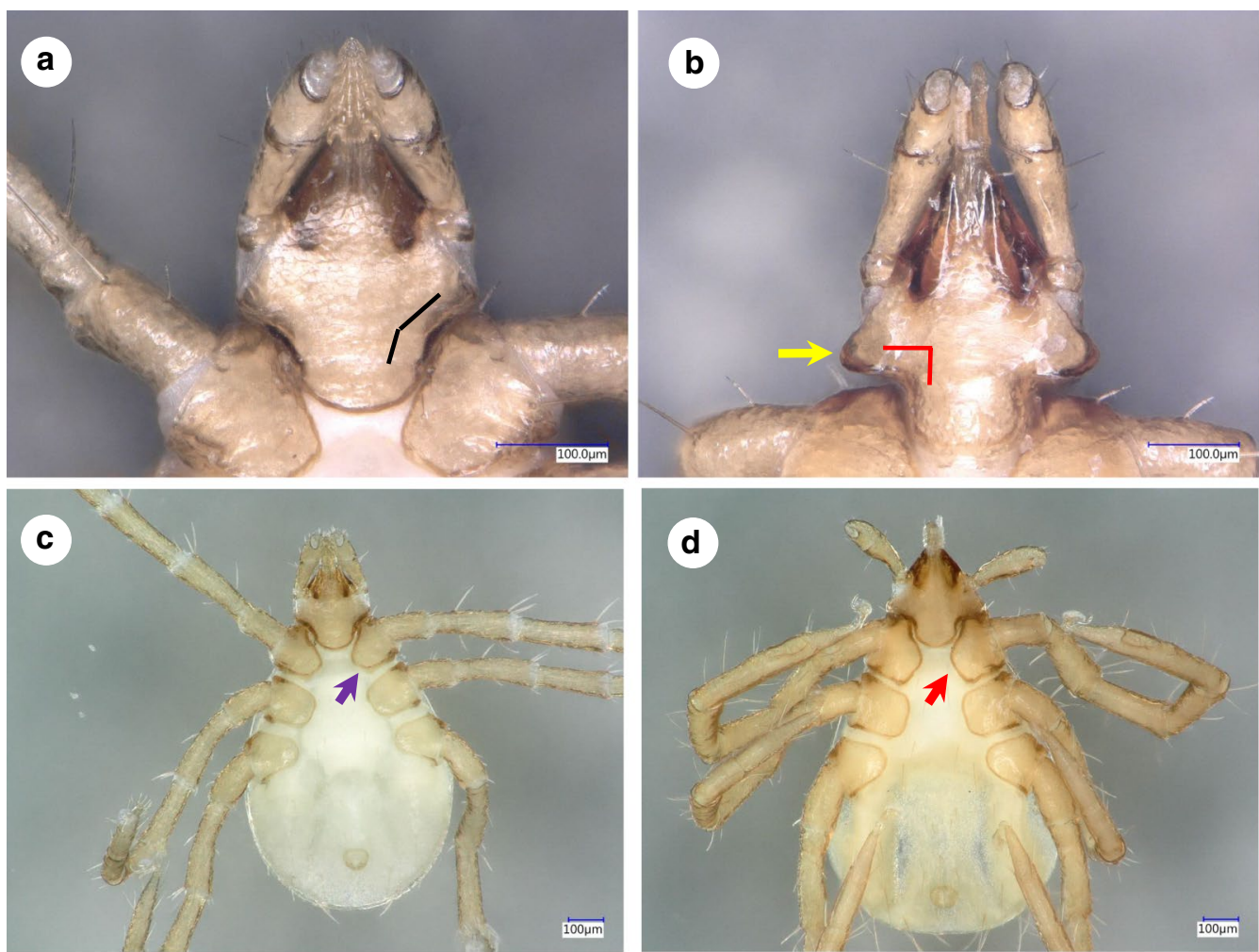

Fig. 6 Ventral views of larvae of Ixodes vespertilionis (a, gnathosoma; c, habitus) and I. collaris (b, gnathosoma; d, habitus). The black and red broken lines illustrate the angle of the caudolateral edge of the gnathosoma. The yellow arrow marks the "collar". The purple and red arrows mark the medial edge of coxa I

short palpi in all stages, unlike I. collaris. The male of $I$. vespertilionis has dense long palpal setae (sparse in I. collaris), whereas its females, nymphs and larvae lack the ventrolateral collar of gnathosoma (characteristic of I. collaris).

\section{Conclusions}

Based on the descriptions above, several features allow to distinguish the male and the larva of I. collaris morphologically from those of other bat-associated ixodid tick species.

\section{Acknowledgements}

The authors are grateful to Mr Nguyen Vu Khoi (director of Wildlife at Risk) and the Management Board of the IEBR for their support in the sample collection. Special thanks to Ms Nóra Takács for performing PCRs.

\section{Funding}

Financial support was provided by NKFIH 115854 and by Rufford Foundation (RGS 18889-B). The publication of this research was supported by the 178964/2018/FEKUTSTRAT grant of the Hungarian Ministry of Human Capacities.

\section{Availability of data and materials}

The sequences generated in this study are available in GenBank database under accession numbers MK450318-MK450321. Ticks morphologically investigated in this study are deposited at the Institute of Ecology and Biological Resources, Vietnam Academy of Science and Technology, Hanoi, Vietnam under the accession numbers VN16-053, VN16-060, VN16-064, VN16-068 and VN17-669). All other relevant data are included in the manuscript.

\section{Authors' contributions}

SH initiated and supervised the study, extracted DNA, described the ticks and wrote the manuscript. JK made the microscopic pictures and DM prepared the drawings. VTT collected the specimens. All authors read and approved the final manuscript.

\section{Ethics approval and consent to participate}

Permissions for bat capture were provided by the Vietnamese Ministry of Agriculture and Rural Development (Vietnam Administration of Forestry), People's Committees of Cao Bang Province and the directorate of Phia Oac - Phia Den National Park (Vietnam), under decree numbers 378/TCLN-BTTN and 1399/ UBND-NC.

\section{Consent for publication}

Not applicable.

\section{Competing interests}

The authors declare that they have no competing interests.

\section{Publisher's Note}

Springer Nature remains neutral with regard to jurisdictional claims in published maps and institutional affiliations.

\section{Author details}

${ }_{1}$ Department of Parasitology and Zoology, University of Veterinary Medicine, Budapest, Hungary. ${ }^{2}$ Plant Protection Institute, Centre for Agricultural Research, Hungarian Academy of Sciences, Budapest, Hungary. ${ }^{3}$ Institute of Ecology and Biological Resources, Vietnam Academy of Science and Technology, Hanoi, Vietnam. ${ }^{4}$ Graduate University of Science and Technology, Vietnam Academy of Science and Technology, Hanoi, Vietnam. 
Received: 29 August 2018 Accepted: 5 February 2019

Published online: 26 March 2019

\section{References}

1. Hornok S, Estrada-Peña A, Kontschán J, Plantard O, Kunz B, Mihalca AD, et al. High degree of mitochondrial gene heterogeneity in the bat tick species Ixodes vespertilionis, I. ariadnae and I. simplex from Eurasia. Parasit Vectors. 2015;8:457.

2. Hornok S, Görföl T, Estók P, Tu VT, Kontschán J. Description of a new tick species, Ixodes collaris n. sp. (Acari: Ixodidae), from bats (Chiroptera: Hipposideridae, Rhinolophidae) in Vietnam. Parasit Vectors. 2016:9:332.
3. Wilson N. New distributional records of ticks from Southeast Asia and the Pacific (Metastigmata: Argasidae, Ixodidae). Oriental Insects. 1970;4:37-46.

4. Arthur DR. The Ixodes ticks of Chiroptera (Ixodoidea, Ixodidae). J Parasitol. 1956;42:180-96.

5. Feider Z. Ixodoidea. In: Fauna of the Popular Republic of Romania volume 5/2. Bucharest: Academiei Republicii Populare Romane; 1965. pp. 154-173 (In Romanian).

6. Sándor AD, Kontschán J, Plantard O, Péter Á, Hornok S. Illustrated redescription of the male of Ixodes simplex Neumann, 1906. Ticks Tick Borne Dis. 2018;9:1328-30.

7. Hornok S, Kováts D, Angyal D, Dányi L, Kovács R, Kontschán J. Description of the male and the larva of Ixodes ariadnae Hornok, 2014. Ticks Tick Borne Dis. 2016;7:1252-5.
Ready to submit your research? Choose BMC and benefit from:

- fast, convenient online submission

- thorough peer review by experienced researchers in your field

- rapid publication on acceptance

- support for research data, including large and complex data types

- gold Open Access which fosters wider collaboration and increased citations

- maximum visibility for your research: over $100 \mathrm{M}$ website views per year

At BMC, research is always in progress.

Learn more biomedcentral.com/submissions 